\title{
Family and species composition of fishes caught from Marudu Bay, Sabah, Malaysia
}

\begin{abstract}
The present study revealed that the biochemical constituent with respect to different maturity stages of Nemipterus japonicus fish is associated with reproductive cycle, storage and utilization of reserves. Gonadosomatic index N. Japonicus recorded high values $(3.5$ and $0.51)$ in May and low values (0.4 and 0.25) in February for female and male, respectively. The maturity stages was classified into 5 maturity stages as follow, 1) immature stage, 2) maturing stage, 3) mature stage, 4) ripe stage and 5) spent stage. The spawning season of $N$. japonicus extend from May to September. The biochemical composition in muscle, liver and gonad in both sexes are found higher in early stages of maturity and decreases during gonad maturation. The muscle had more fat and crude protein content during the immature stage. Early stages of maturation, hence offer greater food value in these species. With the advancement of maturity, a drop in the fat and soluble crude protein was observed, whereas a linear relationship with moisture was noted from immature to mature stage. The composition of muscle always demonstrated an inverse relationship with hepatic and gonadal composition. Highest crude protein percentage was in stage IV $(72.0 \pm 2.22)$ in ovary. The total crude lipid percentage of the ovary showed a gradual increase from Stage I $(5.1 \pm 0.47)$ to Stage IV $(21.8 \pm 1.02)$
\end{abstract}

Keywords: Family, Species, Fish composition, Marudu bay, Sabah
Volume 2 Issue 5 - 2015

Mohd Azim Bin Mohd Khatib
National Institute of Oceanography and Fisheries, Egypt

Correspondence: Mohd Azim bin Mohd Khatib, Department of Aquaculture, Faculty of Agriculture, Universiti Putra Malaysia, 43400 UPM Serdang, Selangor, Malaysia, Tel +60199847392, Emailazmm_1988@yahoo.com.my

Received: January 27, 2015 | Published: September 10, 2015

\section{Introduction}

Currently, there are various definition for estuaries, but generally, they are partially enclosed bodies of water where freshwater mixes with oceanic saltwater to produce a mixed and fluctuating salinity environment. ${ }^{1-3}$ The estuaries can be perceived as an ideal environment for numerous aquatic species despite a constant change in salinity, temperature and turbidity. ${ }^{4-8}$ Estuaries are recognized worldwide as main breeding centers and nurseries many fish species due to their highly diverse and productive macrofauna ${ }^{9-12}$ Hence, specific areas in estuaries such as mangrove forests and seagrass meadows are favorite places for estuarine fishes to spawn as they can ideally be used as sheltered areas for juvenile fishes. ${ }^{13-16}$

For the record, there had been several studies on fish identification and composition in the estuaries of Peninsular Malaysia. ${ }^{17-23}$ The findings from those studies can be used to help researchers and government authorities in finding better ideas and actions in improving estuarine ecosystem management in Peninsular Malaysia. Unfortunately, the information and studies about fish composition in the estuarine areas of Sabah and Sarawak are still scarce due to the lack of funding, logistic and expertise. ${ }^{24-26}$ Realizing this, for the past few years, the government reacts by beginning extensive fisheries research in Sabah and Sarawak. As a result, Marudu Bay, one of well-known estuary in Sabah, had been selected for the study of fish composition.

The role of Marudu Bay as one of important fishery areas in Sabah cannot be denied as nowadays, many fishery activities such as capture fishery, cage aquaculture, mollusk culture and fish-product processing are operated there. ${ }^{27}$ As a result, adequate and update information about fisheries status in Marudu Bay are needed in order for the authorities to manage the fish stocks effectively. Unfortunately, recent records showed that there was very little or no comprehensive information about fish composition in Marudu Bay. ${ }^{24}$ The knowledge and identification of fish assemblage in Marudu Bay is quite essential as the study of fish diversity at there cannot be executed unless the study of fish composition had been done first. Hence the objective of this chapter was to identify and find the composition of fishes, up to the species level, found in the estuaries from Marudu Bay, Sabah, East Malaysia. This study will provide first sufficient and comprehensive data about fish composition in Marudu Bay, thus enabling further studies about fish diversity in the later chapter.

\section{Materials and methods}

The study was conducted at Marudu Bay in the coastal waters of Kota Marudu, Sabah, East Malaysia (Figure 1). The coastline of Kota Marudu is short $(70 \mathrm{~km})$ compared to the other districts in Sabah, with only $4 \mathrm{~km}$ along the mainland, $33 \mathrm{~km}$ along lagoons and $33 \mathrm{~km}$ along islands. Monthly samplings were conducted between October 2012 and September 2013. The sampling activities were carried out during daylight when the tides were high. A medium sized motor boat with a 14 horse power engine was used as transportation to the sampling stations. Fish samples were collected by using gill nets. Upon being ready, the specimens were brought onto land and kept on crushed ice until analysis. The family and species identifications of the sample began by carefully looking at their morphological appearance. The fishes were identified by using a reference book $^{28}$ and fisheries manual. ${ }^{29}$ The samples were then sorted according to the family and species level.

\section{Results and discussion}

In total 40 species of fish and crustaceans belonging to 29 families were identified from the estuary and coastal area of Marudu Bay, Sabah, East Malaysia (Table 1). In terms of species diversity, Carangidae (3 species) and Leiognathidae (3 species) were amongst the most dominant families. Seven families (Portunidae, Terapontidae, Serranidae, Clupeidae, Sciaenidae, Engraulidae and Scombridae) consisted of two species while the other 20 families 
(Ariidae, Centriscidae, Penaeidae, Gerreidae, Paralichthyidae, Nemipteridae, Dasyatidae, Sillaginidae, Belonidae, Mugilidae, Mullidae, Scatophagidae, Lutjanidae, Tetraodontidae, Eleotridae, Soleidae, Cynoglossidae, Squillidae, Sphyraenidae and Atherinidae) had only one species per family.

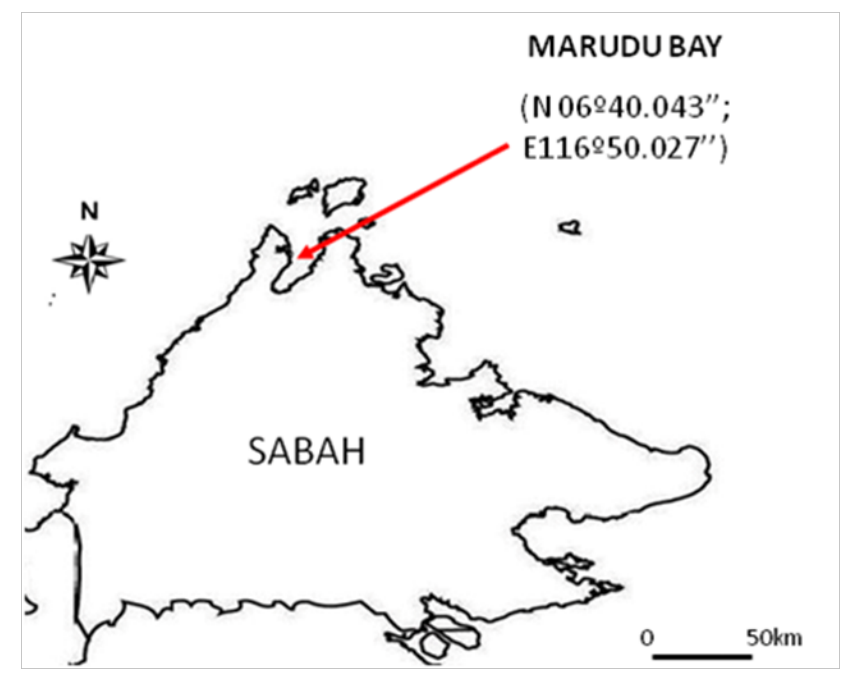

Figure I Geographical location of the sampling stations in the Marudu Bay, Sabah, Malaysia.

Based on Table 2, it can be said that each study used different types of fishing gear, resulting in species diversity differences. It is understood that the types of fishing gears (depending on the manpower and logistics) and also the time of fishing (during high or low tide; day or night) can be attributed as the main reasons for this diversity. ${ }^{23}$ The present and previous studies also showed that neither fish larvae or juveniles, which were always abundant in the estuary areas, were caught during sampling as they can simply pass through the mesh net, implying that only big and mature fish were caught during sampling. Therefore, the collection of fish larvae and juveniles for more detailed studies of fish fauna in estuary areas can only be achieved by using suitable sampling gears. For example, a plankton net or bongo net have more suitable features such as micro mesh sizes and a fixed main frame for trapping small fish. ${ }^{19,23}$

A previous study in Mengkabong Bay, Sabah, found 91 fish species belonging to 40 families. ${ }^{19}$ They used three types of nets including a trammel net, gill net and cast net to catch the fish while our present study sampled fish by only using a gill net. The use of multiple types of nets may have contributed to the higher occurrence of species diversity and abundance than our present study as the practice of using several fishing gears at the same time can potentially lead to a higher catch rate of fish. ${ }^{19}$ From this, we can suggest that it is a good idea to use various net types whenever commencing fish sampling as it can yield sufficient findings in terms of fish diversity and distribution.

Trammel and gill nets are considered to be more popular than other fishing gears for fish sampling as indicated in Table 2 where five out of seven previous studies used these nets as main fishing gears. ${ }^{19,21,20,23,30}$ The yield from using these nets can be quite good for showing fish diversity and distribution of the targeted areas. Evidence can be observed by looking at the structures of these net, which have multiple mean mesh sizes that enable it to trap various fish species with varied body sizes. The passive principal of operation of trammel and gill nets involves casting instead of towing which can prevent much of the fish fauna from extinction as these nets only trap those that try to pass them.

Table I List of fish and crustacean species recorded from estuary and coastal area of Marudu Bay, Sabah

\begin{tabular}{|c|c|c|}
\hline Family & Species (Scientific Name) & Local Name \\
\hline \multirow[t]{2}{*}{ I.Ariidae } & Arius maculates & Ikan duri tompok \\
\hline & Atule mate & Ikan pelata \\
\hline \multirow[t]{2}{*}{ 2. Carangidae } & Scomberoides tol & Ikan talang lampai \\
\hline & Carangoides malabricus & Ikan demudok cermin \\
\hline \multirow[t]{2}{*}{ 3. Sillaginidae } & Sillago sihama & Ikan puntung-damar perak \\
\hline & Eubleekeria splendens & Ikan kekek mahkota \\
\hline \multirow[t]{2}{*}{ 4. Leiognathidae } & Leiognathus equulus & Ikan kekek gedabang \\
\hline & Secutor ruconius & Ikan sekiki india \\
\hline 5. Tetraodontidae & Lagocephalus gloveri & Ikan buntal pisang-perang \\
\hline 6. Paralichthyidae & Pseudorhombus cinnamoneus & Ikan sebelah kayu manis \\
\hline 7. Centriscidae & Centriscus cristatus & Ikan pisau lipat \\
\hline 8. Gerreidae & Gerres oyena & Ikan kapas laut \\
\hline \multirow{2}{*}{ 9. Serranidae } & Epinephelus coiodes & Ikan kerapu bintik jingga \\
\hline & Epinephalus sexfasciatus & Ikan kerapu bebeh \\
\hline \multirow{2}{*}{ 10. Sciaenidae } & Otolithes ruber & Ikan tengkerong panjang \\
\hline & Dendrophysa russselii & Ikan gelama-janggut tanda \\
\hline I I. Nemipteridae & Nemipterus nemurus & Ikan kerisi spina merah \\
\hline \multirow{2}{*}{ 12. Clupeidae } & Sardinella melanura & Ikan tambam-sisik hujung hitam \\
\hline & Sardinella zunasi & Ikan tambam \\
\hline \multirow{2}{*}{ 13. Engraulidae } & Encrasicholina devisi & Ikan bilis laut \\
\hline & Thryssa hamiltonii & Ikan kasai minyak \\
\hline \multirow{2}{*}{ 14. Terapontidae } & Pelates quadrilineatus & Ikan kerong empat jalur \\
\hline & Rhynchopelates oxyrhynchus & Ikan kerong tompok \\
\hline I5. Belonidae & Tylosurus acus melanotus & Ikan todak banang \\
\hline 16. Dasyatidae & Himantura walga & Ikan pari ketuka tanjung \\
\hline \multirow{2}{*}{ 17. Scombridae } & Scomberomorus semifasciatus & Ikan Tenggiri Papan kuning \\
\hline & Rastrelliger kanagurta & Ikan kembung borek \\
\hline 18. Scatophagidae & Scatophagus argus & Ikan kitang \\
\hline
\end{tabular}


Table Continued...

\begin{tabular}{lll}
\hline Family & Species (Scientific Name) & Local Name \\
\hline I9. Mugilidae & Liza tade & Ikan belanak tade \\
20.Mullidae & Parupeneus forsskali & Ikan biji nangka karang \\
21. Lutjanidae & Lutjanus lemniscatus & Ikan jenahak jalur kuning \\
22. Eleotridae & Butis butis & Ikan ubi muncung itik \\
23. Soleidae & Synaptura commersonnii & Ikan lidah-daun tirus \\
24. Cynoglossidae & Cynoglossus bilineatus & Ikan lidah pasir \\
25. Sphyraenidae & Sphyraena putnamae & Ikan alu-alu gigi gergaji \\
26. Atherinidae & Atherinomorus duodecimalis & Ikan paku-renyau perak \\
27. Portunidae & Portunus pelagicus & Ketam bunga \\
& Scylla serrate & Ketam nipah \\
28. Squillidae & Harpiosquilla harpax & Udang lipan \\
29. Penaeidae & Metapenaeus ensis & Udang pasir
\end{tabular}

Table 2 Comparison table of fish classification (total number by family and species) and types of gears that were used to catch fish between the present study and previous regional studies

\begin{tabular}{|c|c|c|c|c|c|}
\hline \multirow{2}{*}{ S. No } & \multirow{2}{*}{ Location } & \multicolumn{2}{|c|}{ Fish Classification } & \multirow{2}{*}{ Type Of Gears } & \multirow{2}{*}{ Source } \\
\hline & & Family & Species & & \\
\hline $\mathrm{I}$ & Marudu Bay (Malaysia) & 29 & 40 & Gill net & Present study \\
\hline 2 & Sungai Pulai seagrass beds (Malaysia) & 37 & 72 & Trammel net & Jimmy ${ }^{23}$ \\
\hline 3 & Tanjung Pelepas (Malaysia) & 30 & 47 & Trammel net & Arshad et al. ${ }^{21}$ \\
\hline 4 & Merchang estuary and seagrass areas (Malaysia) & 19 & 32 & Trammel net and cast net & Suryana ${ }^{20}$ \\
\hline 5 & Mengkabong Bay (Malaysia) & 40 & 91 & Trammel net, gill net and cast net & Mazlan et al. ${ }^{19}$ \\
\hline 6 & Bangrong estuary (Thailand) & 48 & 95 & Push net and gill net & Poovichiranon \& Satapoomin ${ }^{30}$ \\
\hline 7 & Gulf of Thailand (Thailand) & 29 & 38 & Trawl net & Sudara et al. ${ }^{3 !}$ \\
\hline 8 & North Bais Bay (Philippines) & 48 & 49 & Beam trawl & Dollar 32 \\
\hline
\end{tabular}

Instead of using small nets, the neighboring countries of Malaysia such as Thailand and Philippines use big nets like trawl nets ${ }^{31}$ and beam trawls ${ }^{32}$ as the main method of sampling fish. The results from those studies were not much different from the present study as observed from Table 4.2. The number of families and species obtained were 29 families, 38 species $^{31}$ and 48 families, 49 species, ${ }^{32}$ respectively, almost close with the present study in which 29 families and 40 species were obtained. The degree of fish family and species diversity that were recorded from those studies should be distinctively higher than the present study, considering the fact that gill nets are a passive fishing gear while trawl nets and beam trawls are active fishing gears. However, this was not the case as the main reason lies on the operation of those nets. The trawling operation by trawl nets and beam trawls indiscriminately sweep all forms of fishes (juveniles and adults) found in the study areas, with a high chance of getting a high catch yield of only several dominant species, thus ignoring other less dominant species that are scattered in the study areas. ${ }^{23}$ Due to this inefficiency, it is suggested that the use of trawl nets should be limited and instead, passive fishing gears should be encouraged in any fish sampling activities to ensure better results in the observations of fish diversity. In conclusion, further detailed studies on the family and species composition of the fish and crustacean are needed from more geographical locations of Malaysia for fisheries management in these waters.

\section{Acknowledgments}

None.

\section{Conflicts of interest}

None.

\section{References}

1. Gunter G. Some relationships of estuaries to the fisheries of the Gulf of Mexico. In: Lauff GH (Ed.), American Association or the Advancement of Science, Estuaries Washington D.C, USA. 1967;pp.621-638.
2. Sheridan PF. Comparative habitat utilization by estuarine macrofauna within the mangrove ecosystem of Rookery Bay, Florida. Bulletin of Marine Science. 1992;50(1):21-39.

3. Micheli F, Peterson $\mathrm{CH}$. Estuarine vegetated habitats as corridors for predator movements. Conservation Biology. 1999;13(4):869-881.

4. Bennett BA. A comparison of the fish communities in nearby permanently open, seasonally open and normally closed estuaries in the south-western Cape, South Africa. South African Journal of Science. 1989;8(1):43-55.

5. Potter IC, Hyndes, GA, Baronie FM. The fish fauna of a seasonally closed Australian estuary. Is the prevalence of estuarine-spawning species high? Marine Biology. 1993;116(1):19-30.

6. West RJ, King RJ. Marine, brackish, and freshwater fish communities in the vegetated and bar shallows of an Australian coastal river. Estuaries. 1996;19:31-41.

7. Gray CA, McElligott DJ, Chick RC. Intra- and inter-estuary differences in assemblages of fishes associated with shallow seagrass and bare sand. Marine and Freshwater Research. 1996;47(5):723-735.

8. Chang $\mathrm{CW}$, lizuka Y. Estuarine use and movement patterns of seven sympatric Mugilidae fishes: The Tatu Creek estuary, central western Taiwan. Estuarine, Coastal and Shelf Science. 2012;106:121-126.

9. Williams AB. A survey of North Carolina shrimp nursery grounds. Journal of the Mitchell Society. 1955;71(2):200-207.

10. Boesch DF, Turner RE. Dependence of fishery species on salt marshes: The role of food and refuge. Estuaries. 1984;7(4):460-468.

11. National Research Council (NRC). Understanding Marine Diversity: A Research Agenda for the Nation. National Academy Press, Washington DC. 1995

12. Butler AJ, Jernakoff P. Seagrass in Australia: Strategic Review and Development of an R\&D Plan. CSIRO Publishing, Collingwood, Australia. 1999. 
13. Hutchings PA, Recher HF. The fauna of Careel Bay with comments on the ecology of mangrove and sea-grass communities. Australian Zoologist. 1974;18:99-128.

14. Turner RE. Intertidal vegetation and commercial yields of penaeid shrimp. Transactions of the American Fisheries Society. 1977;106(5):411-416.

15. Orth RJ, Heck KL, van Montfrans J. Faunal communities in seagrass beds: A review of the influence of plant structure and prey characteristics on predator-prey relationships. Estuaries. 1984;7(4):339-350.

16. Minello T. Nekton densities in shallow estuarine habitats of Texas and Louisiana and the identification of essential fish habitat. In: Benaka LR (Ed.), Fish Habitat: Essential Fish Habitat and Rehabilitation, American Fisheries Society, Bethesda, USA. 1999;pp.43-75.

17. Sasekumar A, Leh CMU, Chong VC, et al. The Sungai Pulai (Johor)-A unique mangrove estuary. In: Phang SM, et al. (Eds.), Proc 12th Annual Seminar of the Malaysian Society of Marine Science. A research priority for marine science in the 90's of Malaysia. Malaysian Society Marine Sciences, Kuala Lumpur, Malaysia, pp. 280. 1989.

18. Rajuddin MKM. Species composition and size of fish in seagrass communities of Peninsular Malaysia. In:Chou LM \& Wilkinson CR (Eds.), Third ASEAN Science and Technology Week Conference Proceedings, volume 6. Marine science: Living Coastal resources. Department of Zoology, National University of Singapore and national Science and Technology Board, Singapore. 1992.

19. Mazlan AG, Japar SB, Robecca J, et al. Komuniti ikan dari hamparan rumput laut di Teluk Mengkabong, Kota Kinabalu, Malaysia. Universiti Kebangsaan Malaysia, Bangi, Selangor. 1996.

20. Suryana Y. Komuniti ikan di kawasan hamparan rumput laut dan kawasan tiada hamparan rumput laut di Sungai Merchang, Terengganu. Final year project, Bachelor of Science Fishery. Fakulti Sains Gunaan dan Teknologi, Universiti Kolej Universiti Putra Malaysia, Terengganu, Malaysia. 1997

21. Arshad A, Japar SB, Muta Harah Z. Fishes associated with seagrass habitat. In: Japar SB, et al. (Eds.), Aquatic resource and Environmental Studies of the Straits Malacca: Current Research and Reviews. Malacca Straits Research and Development Centre (MASDEC), Universiti Putra Malaysia, Serdang, Selangor. 2001;pp.81-98.
22. Ho KW. Species Composition, Abundance, Size and Feeding Habits of The Fishes collected from Sg. Pulai seagrass beds. Final year project, Bachelor of Science (Honours) Biology. Biology Department, Faculty of Science and Environmental Studies, Universiti Putra Malaysia. 2002

23. Jimmy AA. Fishes of the Sungai Pulai seagrass beds, Johore. Thesis draft, Master of Science, Biology Department, Faculty of Science, Universiti Putra Malaysia. 2007.

24. Biusing ER. Assessment of Coastal Fisheries in the Malaysian-Sabah portio of the Sulu-Sulawesi Marine Ecoregion (SSME). WWF Malaysia, Buhavan Infotech, Sabah, Malaysia. 2001.

25. Rayner SG. Investment Prospects and Potential in the Fisheries Sector in Sabah. Fisheries Department of Sabah, Malaysia. 2001

26. Jakobsen F, Hartstein N, Frachisse J, et al. Sabah shoreline management plan (Borneo, Malaysia): Ecosystems and pollution. Ocean \& Coastal Management. 2007;50(1-2):84-102.

27. Yusoff FM, Ibrahim FH, Abd AN. Colour of Kota Marudu. Universiti Putra Malaysia Press, Sabah, Malaysia. 2012

28. Ambak MA. Fishes of Malaysia. UMT Press, Terengganu. 2010.

29. Rumpet R, Awang D, Musel J, et al. Distribution, Abundance and Biological Studies of Economically Important Fishes in the South China Sea, Area II: Sarawak, Sabah and Brunei Darussalam Waters. Fisheries Bulletin. 1997;8:353-361.

30. Poovachiranon S, Satapoomin U. Occurrence of fish fauna associated in mangrove-seagrass habitats during the wet season, Phuket, Thailand. Proceedings, third ASEAN-Australia symposium on living coastal resources volume 1. In: Sudara S, et al. (Eds.), Australian Institute of Marine Science, Townsville, Australia, pp. 465-470. 1994

31. Sudara S, Satumanatpan S, Nateekanjanalarp S. Seagrass fish fauna in the Gulf of Thailand. Proc 3rd ASEAN Science and Technology Week Conference. 1992;pp.321-326.

32. Dollar MLL. A survey on the fish and crustacean fauna of the seagras bed in North Bais Bay, Negros Oriental, Philippines. In: Angel C (Eds.), Regional Symposium on Living Resources in Coastal Areas Manila, Philippines. University of the Philippines Diliman, Quezon City, Philippines. 1991;pp.367-377. 